\title{
Performance Appraisals Impact on Attitudinal Outcomes and \\ Organisational Performance
}

\author{
Adnan Ahmed \\ Project Development Officer at Read Foundation Islamabad \\ M. Phil Scholar at Muhammad Ali Jinnah University, Islamabad, Pakistan \\ E-mail: adnan_ms2010@yahoo.com \\ Iftikhar Hussain (Corresponding author) \\ PhD Candidate, School of Management, Shanghai University \\ 99 Shangda Road, Shanghai 200444, PR China \\ E-mail: gulnisar_83@yahoo.com \\ Shakeel Ahmed \\ M. Phil Scholar and Lecturer at Faculty of Administrative Sciences Kotli \\ University of Azad Jammu \& Kashmir, Pakistan \\ E-mail: raja_shakeel77@yahoo.com \\ M. Fraz Akbar \\ M. Phil Scholar at Muhammad Ali Jinnah University \\ Islamabad, Pakistan \\ E-mail: frazitm@hotmail.com
}

\begin{abstract}
Performance appraisal is a widely recognized process, yet in Pakistan efforts to study and examine its effect on attitudinal outcomes and firm performance are scarce. The present study addresses this research gap. Researchers explored the relationship between PA satisfaction, job satisfaction and turnover intentions in semi-governmental organizations in Pakistan. Using responses collected from 123 respondents, we find statistically significant relationships between studied variables. The results have significant policy implications for improving the process of performance appraisal in semi-governmental organizations in Pakistan as well as other developing countries. Further the study enriches the body of knowledge on performance appraisal and its impact on organizational performance in developing countries.
\end{abstract}

Keywords: Performance appraisal, SGOs, Job satisfaction, Turnover, PA

\section{Introduction}

Both public and private sector employ formal employee appraisal systems increasingly. Performance appraisal (PA) usually involves 'evaluating performance based on the judgments and opinions of subordinates, peers, supervisors, other managers and even workers themselves' (Jackson \& Schuler 2003). An employee appraisal, PA, performance review, or (career) development discussion is a method by which the job performance of an employee is evaluated (generally in terms of quality, quantity, cost, and time). PA is a part of career development. Performance appraisals (PAs) are regular reviews of employee performance within organisations. $\mathrm{PA}$, as a process is seen as a key contributor to successful human resource management, as it is strongly related to organisational performance (Erdogan 2002). According to Cardy and Dobbins (1994), PA as a process of enhancing human performance has attracted the attention of both academics and practitioners.

A common process for managing employees is the traditional practice of annual performance reviews. While these annual reviews have their shortcomings, companies around the globe continue to use them. However, to 
increase accuracy and to get a comprehensive and balanced feedback about employee performance, 360-degree feedback system is becoming popular. In this system peers, subordinates and customers also do the appraisal. This is particularly relevant in the light of research, which has empirically proved that 360-degree feedback system improves employee performance significantly (Rai \& Singh 2005).

PA is centrally managed by the human resource department in semi-governmental organisations (SGOs). Generally, the aims of a PA are to give feedback on performance to employees, identify employee training needs, document criteria used to allocate organisational rewards, form a basis for personnel decisions: salary increases, promotions, disciplinary actions, provide the opportunity for organisational diagnosis and development, facilitate communication between employee and administration and validate selection techniques and human resource policies to meet federal equal employment opportunity requirements.

PAs fairness is a hot issue. Researchers and practitioners are trying to devise means in order to increase employees' productivity and reduce turnover, without adding a significant increase in costs? The PA fairness has been cited as a way of achieving these goals (Thomas \& Bretz 1994). Despite its paramount significance, literature reveals that in Pakistan there were few studies on this issue. This study was designed to fill this gap. The study examined the relationship of PA satisfaction/fairness with employee job satisfaction and turnover intentions. Further study highlighted the PA systems adopted in SGOs in Pakistan and their impact on organisational performance. Data from 123 employees working in SGOs based in Islamabad Pakistan were used to test the hypothesized relationships. The study also highlighted the weaknesses of existing PA practices in Pakistan. Some modifications in the PA system currently practiced in SGOs were also recommended in the light of results from questionnaire and HR literature.

The structure of this article, consistent with its objectives, is as follows. After this introduction, we present a theoretical review that enables us to delimit the relationships among PA, PA and employee job satisfaction and PA and turnover intentions. Literature both, from international world as well as from Pakistan was discussed. Section 3, outlines the research design and the methods used in the study. Section 4, contain results followed by Section 5, contains discussions, findings and implications of the study for research and practice.

\section{Review of Literature}

Performance management, in its broadest context, is a managerial process that links corporate objectives, performance standards and evaluation, to which the performance review, or PA, are often applied (Pickett 2003). PAs are introduced for multiple purposes. Bernardin and Beatty (1984), highlighted several objectives of PA, like to improve the use of resources and serve as a basis for personnel actions. Cleveland, Mohammed, Skattebo and Sin (2003), described four purposes of PA: to make distinctions among people, distinguish a person's strengths from his or her weaknesses, implement and evaluate human resource systems in organisations, and document personnel decisions. Cleveland, et al. (2003) also described that appraisals are used to make between-person decisions, for instance for promotions or termination decisions or salary administration and this purpose of the PA will remain the focus of the present study. However success of any PA system depends upon its degree of fairness.

The relationship between job satisfaction and job performance has been the concern of many studies. Job satisfaction refers to the employee's pleasurable or positive emotional state as a result of the appraisal of one's job and job experiences (Bartlett \& Kang 2004; Judge, Thoresen, Bono \& Patton 2001; Schmidt 2007). For the long-term effectiveness of the organisational system employees' satisfactory perceptions towards PAs are important (Longenecker \& Nykodym 1996; Roberts 1992). If employees are not satisfied with PAs they will not see the added value (Bernardin \& Beatty 1984; Dobbins, Cardy \& Platz-Vieno 1990). Some other studies suggested that appraisal satisfaction is a key factor leading job satisfaction (Moussavi \& Ashbaugh 1995; Murphy \& Cleveland 1995).

PA also effects turnover intention that is, leaving the present job to look for another job and actual turnover (Brown 1996; Egan, Yang \& Bartlett 2004). One of the preeminent purposes of appraisals is to positively affect future performance (Cleveland, Murphy \& Williams 1989; Huffman \& Cain 2000; Swanson \& Holton 2001; Thomas \& Bretz 1994). As Latham, et al. (1993), state the basic purpose of conducting PAs is to improve the performance of the affected employees. The PA purposes like communication of super-ordinate goals, the capacity of PA to increase employees' perceptions of being valued and being part of an organisational team (Levy \& Williams 2004), and the social exchange argument (Lee \& Bruvold 2003), also effect turnover intention. PAs are effective tool for mangers to enhance their organisational effectiveness. Despite of this, managers are reluctant to use PA. According to some studies (DeCarlo \& Leigh 1996; Jaworksi \& Kohli 1991), PA helps in improving performance and building both job satisfaction and organisational commitment. Alternately, this helps 
in lowering down the turnover levels (Babin \& Boles 1996; Babakus, Cravens, Johnston \& Moncrief 1996; Brown \& Peterson 1994). Bard Kuvaas (2006), observed positive findings regarding turnover intention with PA satisfaction, that those employees who are satisfied with how PA is conducted have lower turnover intentions.

PAs in performance management are considered critical. Several studies emphasized fairness of procedures used for PA. Unfair procedures used in PAs create job dissatisfaction (Erdogan 2002; Flint 1999; Murphy \& Cleveland 1991; Nurse 2007; Simmons \& Lovegrove 2002; Taylor, et al. 1995; Vigoda 2000). Some other studies found that for the evaluation process to be effective, it should be perceived as being fair. Further fairness (as measured by perceived equity) is positively related to the employee's level of job satisfaction (Gilliland \& Langdon 1998; Huffman \& Cain 2000; Thomas \& Bretz 1994; Wanguri 1995). In PAs, individuals compare their efforts with the rating they received and the fairness of that rating and develop attitudinal outcomes as reactions (Erdogan 2002).Unfairness in PA processes will affect attitudinal outcomes negatively. As Poon (2004), reported findings indicating that dissatisfaction with PA influenced employees' intention to quit through reduced job satisfaction. In a study Clardy and Dobbins (1994), identified that for PA to positively influence employee behavior and future development employees must experience positive appraisal reactions. If not, any appraisal system will be doomed to failure.

Consequently, PA and its fairness has been the focus of PA research. The PA system currently used in Pakistan mainly serves the determination of appropriateness of pay increments. This is not an appropriate use of a PA system (Fisher, et al. 1997). No studies have investigated PA satisfaction/fairness and its impacts on job outcomes in Pakistan. This study, therefore, takes the views of appraisees in SGOs in Pakistan. Specifically, the broad aim was to explore the relationship between the appraisee's perception of fairness and PA satisfaction, and PA impacts on job satisfaction and employee turnover. Therefore the primary hypotheses studied were;

Hypothesis 1

H1(a). Appraisee's perception of PA fairness is not related to their job satisfaction.

H1(b). Appraisee's perception of PA fairness is positively related to their job satisfaction.

\section{Hypothesis 2}

H2(a). Appraisee's perception of PA fairness is not related to their turnover intentions.

H2(b). Appraisee's perception of PA fairness is negatively related to their turnover intentions.

Hypotheses were established based on the belief that properly conducted PAs can provide numerous organisational benefits in terms of enhancing employees' satisfaction and reducing employees' turnover.

\section{Methodology}

PA system, being practiced in SGOs of Pakistan is commonly known as Annual Confidential Report (ACR) and is kept confidential from the appraisee. Appraisals of all employees are conducted once a year and mostly in December. PA system of SGOs has been evaluated in the study. The following paragraphs discuss the sample, study design, and measures.

\subsection{Sample}

The study examined 250 employees through a survey at SGOs in Islamabad Pakistan. A total of 123 employees completed survey (59.2 percent response rate). Sample selected was a mix of marketing and sales, production and administration departments' employees. Respondents were among three categories of employees including Senior Officers (grade 19 and above), Officers (grade $17 \& 18$ ) and staff (grade 1-16). All 123 respondents were used in the analysis. Around 72 percent of respondents were male, with the largest group for genders falling within the 20-30 age range. All respondents were workers in Pakistani SGOs. All respondents were educated to degree level, with 38 percent having achieved a master degree. In addition, table 1 displays comprehensive profile of the respondents.

\section{Insert table 1 here}

\subsection{Study Design}

All employees were given a formal PA by their immediate supervisor once a year usually in the month of December. A graphic rating scale format was used for the written appraisal. The employees were rated on multiple job dimensions and provided an overall performance rating by their immediate supervisor. Future pay, 
promotions and other rewards are tied to performance ratings. Therefore, performance evaluations require providing a fair and satisfactory rating as future outcomes and employees reactions depends upon PAs outcome.

For the purpose of alleviating problems related with PA satisfaction, its impact on employees' job satisfaction and turnover intentions, data were collected. Respondents were administered through a survey to judge their perception about PA satisfaction, job satisfaction and turnover intentions. The surveys were administered at the organisation site. On completion, respondents returned the surveys directly to the researchers.

\subsection{Measures}

A questionnaire was designed to get input from 123 managers and staff including Initiating Officer, Reporting Officer and Senior Reporting Officer in three SGOs. The survey was pilot-tested with some researcher and professionals in human resource department to ensure that instrument was complete and easy to follow and that the items were not ambiguous. A Likert scale ranging from (1- strongly disagree to 5- strongly agree) was used for survey items on PA satisfaction/fairness and employee attitudes. Pearson correlation was used to test the hypotheses.

Demographic information including gender, age, and number of promotions were also collected. Employees' most recent performance ratings were obtained through organisational records. Employees were given an overall rating by their immediate supervisor in one of four categories: (1) below standards, (2) meets standards, (3) exceeds standards, or (4) distinguished.

\section{Results}

Means and standard deviations for all the variables were calculated in order to get an idea about the direction of the respondents' perceptions. Table 2 indicates the mean values and standard deviations for the studied variables. A low standard deviation for all the variables indicates reliability of the data and less variation in respondents' perceptions. Also all mean values above three indicates the significance of the variables.

\section{Insert table 2 here}

Correlation coefficients' were computed for the studied variables shown in table 3 and 4 . Results from the correlation coefficients were used for hypotheses testing.

\section{Insert table 3 here}

The results in table 3 indicates significant positive correlation between PA satisfaction and job satisfaction $(\mathrm{r}=.848, \mathrm{n}=123, \mathrm{p}<0.0005$, two tailed). Thus, the hypothesis $H 1(a)$ is not supported and the alternative hypothesis H1(b) is supported, a statistically significant relationship does exist. From this result it can be deduced that the perception of PA satisfaction is positively correlated to employee job satisfaction, as the Pearson correlation is significantly large. These results are consistent with previous studies (Bartlett \& Kang 2004; Judge, et al. 2001; Locke 1970; Schmidt 2007).

\section{Insert table 4 here}

The results in table 4 also support a statistically significant relationship ( $r=.-811, \mathrm{n}=123, \mathrm{p}<0.0005$, two tailed), indicating a clear correlation between the respondent's perception of PA satisfaction and employee turnover intentions. Thus, the hypothesis $H 2(a)$ is not supported and the alternative hypothesis $H 2(b)$ is supported, a statistically significant relationship does exist. From this result it can be deduced that the employee turnover intentions are significantly and negatively correlated to perception of PA satisfaction, as the Pearson correlation is significant. The PA satisfaction and employee turnover intention correlation results are consistent with previous studies (Babakus, et al. 1996; Kuvaas 2006).

\section{Conclusion}

The study was conducted to examine the impact of PA satisfaction on employee job satisfaction and turnover intentions in SGOs of Pakistan. The findings of the study have supported the hypotheses depicting that PA is 
positively related to employee job satisfaction and negatively related to turnover intentions. Satisfaction with PA system is important, as dissatisfaction with process negatively affect job performance (Vigoda 2000), and employee satisfaction (Taylor, et al. 1995). The results of the study indicated that present appraisal system in the SGOs has many weaknesses as compared to contemporary HR literature. In order to enhance PA satisfaction among the employees reforms in present system are needed. Consequently, employee job satisfaction will increase and turnover intentions will decrease.

The analysis indicates that lack of necessary skills, knowledge, management support and personal priorities, and the discomfort most employees experience when giving and receiving feedback, are the forces inhibiting this critical process. Failure to set goals and provide ongoing feedback and summary evaluations generally results in employees becoming dissatisfied and result reduced performance. Effective PA systems stand to create a vision of success and a climate in which performers want to give their best and strive for continuous improvement.

PA system being practiced in SGOs' in Pakistan needs much improvement. In order to bring PA satisfaction among employees and to build their trust on the appraisals in SGOs' of Pakistan, research based policies are desired. A better PA system integrated with better HR practices will enhance performance appraisal satisfaction and also increase employee job satisfaction and reduce turnover intentions to bring effectiveness in the organisations. The study has a limitation that it has focused on only SGOs and has small sample size. However, the same will help the researchers to broad their study by focusing governmental or nongovernmental organisations. Further the study enriches the body of knowledge on PA and its impact on organisational performance in developing countries.

\section{References}

Babakus, E., Cravens, D. W., Johnston, M., \& Moncrief, W. C. (1996). Examining the role of organisational variables in the sales person job satisfaction model. Journal of Personal Selling and Sales Management, 16 (3), $33-46$.

Babin, B. J., \& Boles, J. S. (1996). The effects of perceived co-worker involvement and supervisor support on service provider role stress, performance and job satisfaction. Journal of Retailing, 72 (1), 57-75.

Bartlett, K. R., \& Kang, D. (2004). Training and organisational commitment among nurses following industry and organisational change in New Zealand and the United States. Human Resource Development International, 7 (4), 423-440.

Bernardin, H. J., \& Beatty, R. (1984). Performance appraisal: Assessing human behavior at work. Kent Wadsworth Publishing, Boston.

Brown, S. P. (1996). A meta-analysis and review of organisational research on job involvement. Psychological Bulletin, 120 (2), 235-255.

Brown, S. P., \& Peterson, R. A. (1994). The effect of effort on sales performance and job satisfaction. Journal of Marketing, 58 (2), 70-80.

Cardy, R. L., \& Dobbins, G. H. (1994). Performance Appraisal: Alternative Perspectives. South Western Publishing Company, Cincinnati, $\mathrm{OH}$.

Cleveland, J. N., Mohammed, S., Skattebo, A. L., \& Sin, H. P. (2003). Multiple purposes of performance appraisal: A replication and extension. Poster presented at the annual conference for the Society for Industrial and Organisational Psychology, Orlando, FL.

DeCarlo, T. E., \& Leigh, T. W. (1996). Impact of sales person attraction on sales managers' attributions and Feedback. Journal of Marketing, 60 (2), 47-66.

Dobbins, G. H., Cardy, R. L., \& Platz-Vieno, S. J. (1990). A contingency approach to appraisal satisfaction: an initial investigation of the joint effects of organisational variables and appraisal characteristics. Journal of Managemen, 16 (3), 619-632.

Egan, T. M., Yang, B., \& Bartlett, K. R. (2004). The effects of organisational learning culture and job satisfaction on motivation to transfer learning and turnover intention. Human Resource Development Quarterly, 15(3), 279-301.

Erdogan, B. (2002). Antecedents and consequences of justice perceptions in performance appraisals. Human Resource Management Review, 12 (4), 555-578.

Fisher, C. D., Schoenfeldt, C. F., \& Shaw, J. B. (1997). Performance appraisal. Human Resource Management, $3^{\text {rd }}$ edn, pp. 449-502, Houghton Mifflin Publishing, Boston. 
Flint, D.H. (1999). The role of organisational justice in multi-source performance appraisal: Theory-based application and direction for research. Human Resource Management Review, 9 (1), 1-20.

Gilliland, S. W., \& Langdon, J. C. (1998). Creating performance management systems that promote perceptions of Fairness. In J. W. Smither (Ed.), Performance appraisals: A state of the art in practice, pp.209-243. San Francisco: Josey-Bass.

Huffman, C., \& Cain, L. B. (2000). Effects of considering uncontrollable factors in sales force performance Evaluation. Psychology \& Marketing, 17 (9), 799-833.

Jackson, S.E., \& Schuler, R.S. (2003). Managing human resources through strategic partnerships. (8th ed.) Mason, Ohio: Thomson-Southwestern.

Jaworski, B. J., \& Kohli, A. K. (1991). Supervisory feedback: alternative types and their impact on salespeople's performance and satisfaction. Journal of Marketing Research, 28 (2), 190-201.

Judge, T. A., Thoresen, C. J., Bono, J. E., \& Patton, G. K. (2001). The job satisfaction-job performance relationship: A qualitative and quantitative review. Psychological Bulletin, 127 (3), 376-407.

Kuvaas, B. (2006). Performance Appraisal Satisfaction and Employee Outcomes: Mediating and Moderating Roles of Work Motivation. International Journal of Human Resource Management, 17 (3), 504-522.

Latham, G. P., Skarlicki, D., Irvine, D., \& Siegel, J. P. (1993). InC. L. Cooper \& J. T. Robertson. Eds.Vol.8, Chap.3, pp. 87-133. London: John Wiley \& Sons.

Lee, C.H., \& Bruvold, N.T. (2003). Creating value for employees: investment in employee development. International Journal of Human Resource Management, 14 (6), 981-1000.

Longenecker, C. O., \& Nykodym, N. (1996). Public sector performance appraisal effectiveness: a case study. Public Personnel Management, 25 (2), 151-165.

Moussavi, F., \& Ashbaugh, D. L. (1995). Perceptual effects of participative, goal-orientated performance appraisal: a field study in public agencies. Journal of Public Administration Research and Theory, 5 (3), 331-344.

Murphy, K.R., \& Cleveland, J.N. (1991). Performance Appraisal: An organisational perspective. Needham Heights, MA, Allyn \& Bacon.

Murphy, K.R., \& Cleveland, N.J. (1995). Understanding performance appraisal - Social, organisational and goal based perspective. Thousand Oaks: Sage Publications.

Nurse. L \& Devonish, D. (2007). Grievance management and its links to workplace justice. Employee Relations, 29 (1), 89-109.

Pickett, L. (2003). Transforming the Annual Fiasco, Industrial and Commercial Training. MCB Up Limited, 35 (6), 237-240.

Poon, J. M. L. (2004). Effects of Performance Appraisal Politics on Job Satisfaction and Turnover Intention. Personnel Review, 33 (3), 322-334.

Rai, H., \& Singh, M. (2005). Mediating effects in the relationship between 360-degree feedback and employee Performance. Working paper no. 2005-04-06, IIM Ahmedabad

Roberts, G. E. (1992). Linkages between performance appraisal system effectiveness and rater and rate acceptance. Review of Public Personnel Administration, 12 (3), 19-41.

Schmidt, S. W. (2007). The relationship between satisfaction with workplace training and overall job satisfaction. Human Resource Development Quarterly, 18 (4), 481-498.

Simmons, J. A., \& Lovegrove, I. W. (2002). Negotiating a research method's conceptual terrain: lessons from a stakeholder analysis perspective on performance appraisal in universities and colleges. Paper presented at the European Conference on Research Methods in Business and Management.

Swanson, R. A., \& Holton, E. F. (2001). Foundations of human resource development. Berrett-Koehler Publishers, San Francisco.

Taylor, M.S., Masterson, S.S., Renard, M.K., Harrison, J.K., \& Carroll, S.J. (1995). Due process in performance appraisal: a quasi-experiment in procedural justice. Administrative Science Quarterly, 40 (3), 495-523.

Thomas, S. L., \& Bretz, R. D., Jr. (1994). Research and practice in performance appraisal: Evaluating performance in America's largest companies. SAM Advanced Management Journal, 22 (2), 28-37. 
Vigoda, E. (2000). Organisational Politics, Job Attitudes, and Work Outcomes: Exploration and Implications for the Public Sector. Journal of Vocational Behavior, 57 (3), 326-347.

Wanguri, D. M. (1995). A review, integration, and a critique of cross- disciplinary research on performance appraisals, evaluations, and feedback: 1980-1990. The Journal of Business Communication, 32 (3), 267-293.

Table 1. Respondents' Profile

\begin{tabular}{lcc}
\hline Characteristics & N & Percentage \\
\hline Age (years) & 68 & 55.3 \\
$\begin{array}{l}\text { Gender } \\
\text { Male }\end{array}$ & 89 & 72.3 \\
$\begin{array}{l}\text { Education } \\
\text { Masters or above }\end{array}$ & 47 & 38.2 \\
Job position & \\
$\begin{array}{l}\text { Officer (above grade 16) } \\
\text { Type of organization }\end{array}$ & 45 & 36.5 \\
SGOs & 123 & 100 \\
\hline
\end{tabular}

Table 2. Descriptive Statistics

\begin{tabular}{lcccc}
\hline \multicolumn{5}{c}{ Descriptive Statistics } \\
\hline \multirow{2}{*}{$\mathbf{N}$} & Valid & 123 & 123 & 123 \\
& Missing & 00 & 00 & 00 \\
Mean & & 3.3740 & 3.0732 & 3.0244 \\
Std. Deviation & .95298 & .88864 & .88209 \\
\hline
\end{tabular}

Table 3. Correlation Coefficients

\begin{tabular}{llcc}
\hline \multicolumn{3}{c}{ Correlations } \\
\hline \multirow{5}{*}{ PA satisfaction } & PA satisfaction & Job satisfaction \\
& Pearson Correlation & 1 & $.848^{* *}$ \\
& Sig. (2-tailed) & & .000 \\
& $\mathrm{~N}$ & 123 & 123 \\
\multirow{5}{*}{ Job satisfaction } & Pearson Correlation & $.848^{* *}$ & 1 \\
& Sig. (2-tailed) & .000 & 123 \\
& $\mathrm{~N}$ & 123 & \\
\hline **. Correlation is significant at the 0.01 level (2-tailed). \\
\hline
\end{tabular}

Table 4. Correlation Coefficients

\begin{tabular}{llcc}
\hline \multicolumn{3}{c}{ Correlations } \\
\hline \multirow{3}{*}{ PA satisfaction } & PA satisfaction & Turnover intentions \\
& Pearson Correlation & 1 & $-.811^{* *}$ \\
& Sig. (2-tailed) & & .000 \\
& $\mathrm{~N}$ & 123 & 123 \\
Turnover intentions & Pearson Correlation & $-.811^{* *}$ & 1 \\
& Sig. (2-tailed) & .000 & 123 \\
& $\mathrm{~N}$ & 123 & \\
\hline **. Correlation is significant at the 0.01 level (2-tailed). \\
\hline
\end{tabular}

